\title{
Determination of Optimal Surface Area to Volume Ratio for Thin-Layer Drying of Breadfruit (Artocarpus altilis)
}

\author{
C. George \\ Assistant Professor \\ School of Engineering, \\ University of St. Thomas \\ St. Paul, MN, USA \\ cmgeorge@stthomas.edu \\ R. McGruder and K. Torgerson \\ Seniors, School of Engineering, \\ University of St. Thomas \\ St. Paul, MN, USA \\ Ross.McGruder@AndersenCorp.com \\ kmtorgerson@gmail.com
}

\begin{abstract}
Experiments to determine the optimal size shred of breadfruit for sun drying in the Caribbean were conducted and verified. To determine optimal shred size, ease of shredding and handling as well as the drying characteristics were considered. Additional experiments compared the drying characteristics of breadfruit to several types of produce more readily available for use in the laboratory and examined the effect of alternative bases or backgrounds for sun drying. An optimal surface area to volume ratio is recommended and found to dry breadfruit under average Caribbean conditions $\left(27-30{ }^{\circ} \mathrm{C}\right.$, $60-65 \% \mathrm{RH}, \sim 800 \mathrm{~W} / \mathrm{m}^{2}$ solar radiation and $1.5-2.0 \mathrm{~m} / \mathrm{s}$ prevailing winds) in about three hours.
\end{abstract}

Index Terms - Breadfruit drying, open sun drying, shred size, thin-layer drying.

\section{INTRODUCTION}

A large portion of agricultural surpluses are lost in developing countries. To process and preserve post-harvest produce successfully, spoilage agents must be destroyed and nutritional value preserved. One method of preserving post-harvest surplus is drying. The water content of the produce must be reduced to a level insufficient for growth of microorganisms and a level low enough to slow down the action of enzymes. The reduction of water content is produce-specific with critical levels often cited to be about $10-15 \%$ moisture, depending on the commodity. ${ }^{1}$

Breadfruit (Artocarpus altilis) is a carbohydrate found throughout the islands of Oceania and the Caribbean and is commonly consumed in the green, partially immature stage as a vegetable. ${ }^{2,3}$ Breadfruit is highly perishable with post-harvest ripening and softening in just 1-3 days after harvest which restricts its marketing and limits its export potential as fresh produce. It is a seasonal crop producing one or occasionally two crops per year. It is estimated that between $50-70 \%$ of the available breadfruit in Haiti is lost to spoilage. ${ }^{4}$ The motivation of the study documented in this paper was to recommend a breadfruit dehydration process that was fast, inexpensive, safe and suitable for the Haitian climate and culture. However, any area where breadfruit grows readily can benefit from these results. 
Dried products can be used in a variety of ways. Dried breadfruit can be ground finely and made into flour. It can also be re-hydrated before cooking. As part of a larger program of food processing directed toward village level entrepreneurs, drying breadfruit can increase food supply, improve seasonal food choice, possibly generate income, and decrease excessive dependence on imported processed foods.

The drying strategy for any given application should consider batch size, drying characteristics of the products, initial and final moisture contents of the product, availability and reliability of electrical power, weather conditions, production capacities and investment capabilities of the farmers, and potential markets for the dried product. The socio-economic condition of the users needs to be given top priority.

A review of the literature concerned with the general study of drying agricultural products often involves predicting the produce behavior during drying or examines different drying technologies. Numerous articles in the literature look at the drying kinetics of produce. , $^{3,6,6,7,8,9}$ Experimental studies are aimed at investigating the most suitable drying conditions (temperature, air velocity) while still maintaining high quality of food (nutrition, color) ${ }^{10}$ as well as minimizing or eliminating commercial energy usage. These semi-empirical studies entail multiple regression analysis and statistical tests to confirm the consistency of a selected model and the choice of correlation coefficients. Theoretical modeling investigations apply mass and energy balances across a thin-layer of product subjected to a set of temperature and flow conditions and utilize numerical methods to solve the coupled equations. ${ }^{11,12,13}$ Such studies look to understand the drying phenomenon or to further reduce drying time by looking at intermittent and stepwise drying as an alternative to continuous drying. ${ }^{14}$ Enclosed drying methods provide protection against rain and contamination and usually reduce drying time. Enclosed systems described in the literature increase post-harvest efficiency or reliability by having precise control over drying variables. ${ }^{15,16,17}$ Mechanized drying is usually the fastest with optimized conditions, but requires fuel or electricity to operate. Solar cabinet or tunnel drying uses some technology, have lower operating costs and can be completely passive (natural convection) ${ }^{18,19,20}$ or use mechanical fans (forced convection) $^{21,22}$.

The most common method for drying produce is open air drying which can be done in direct sunlight or under shaded conditions. Sunlight heats food effectively driving out moisture but direct sunlight and heat can destroy fragile vitamins and can cause food to lose color. ${ }^{23}$ Breadfruit can tolerate direct sunlight with good preservation of protein, carbohydrate and trace nutrients $^{24}$ and thus is a suitable candidate for open air sun drying. However, there is no tradition of drying breadfruit or preserving breadfruit in Haiti or other islands of the Caribbean. Some traditional preserving techniques for breadfruit exist in the South Pacific. Dusting with wood ash has been used to prolong the shelf life of breadfruit in Pohnpei, in the Federated States of Micronesia. In this case the ash alkalinity is hostile to molds and bacteria. Breadfruit has also been preserved by a combination of drying and smoking. It can be cut into slices, suspended over a fire and then smoked with green tree bark. Fry- drying has also been documented as an option for preservation. ${ }^{25}$

Any strategy for the preservation of breadfruit in Haiti should avoid requiring electricity (unavailable or unreliable) or the burning of biomass (to avoid further Haitian deforestation). Thus smoking/drying over a fire or fry-drying are not realistic approaches to harvesting surplus breadfruit. However, the Caribbean has ample sunshine throughout the year, thus sun drying could be a promising option for some of its food preservation needs. 
The relative humidity of the ambient air is one of the key drying variables. As dry air moves over moist produce it absorbs water from the produce. The resulting air temperature decreases and its relative humidity increases. The drying capacity of air can be increased by heating it. Enclosed drying strategies often include heating of the air by using solar or biomass heat. ${ }^{26}$ Drying temperatures must be in a range that are high enough to give rapid moisture removal but not so high as to cook the produce. If the temperature is too high the food can cook on the outside causing the produce to 'case harden', a situation where the outer layer is hard and prevents moisture in the inside from escaping. ${ }^{27}$ The core of the produce remains moist and will eventually mold.

Cutting large size produce into small pieces has been mentioned by authors ${ }^{15,19}$ as a way to accelerate drying due to increased surface area of the product and also avoid case hardening. For general food drying, it is commonly recommended to cut produce into thin pieces of not more than about $0.6-1.0 \mathrm{~cm}(1 / 4-3 / 8$ inch $) .{ }^{28} \mathrm{~A}$ sweep of the literature only found one reference to breadfruit drying ${ }^{29}$ which led to an internal report that documented breadfruit cut into $1 \mathrm{~cm}$ thick slices for use in a passive solar dryer. ${ }^{30}$ These authors successfully dried breadfruit in the Pacific Islands until it was dry and brittle. Their study examined post-drying storage requirements in tropical conditions. No other papers were found that explicitly considered optimal shred size to promote efficient produce drying.

The series of experiments documented in this paper were performed as part of a larger recommendation for a cost effective process to harvest unused breadfruit. Currently small scale farmers do not preserve breadfruit in the Caribbean. The research outlined in this paper was done for the Committee on Development for the Methodist Church of Haiti. During a preliminary process exploration conducted in July 2003, several small scale farmers in Haiti were asked to sun dry $25 \mathrm{~kg}$ of breadfruit. The farmers used a large knife to peel off the outer skin, remove the hard inner core, and then sliced the breadfruit into lengthwise pieces. Each of the farmers sliced the breadfruit a little differently and often the slices became thicker with each consecutive breadfruit. The slicing process was somewhat difficult and took a long time. The slices dried unevenly. Only a small percentage of the breadfruit dried in the same day. Case hardening of the thick pieces was observed. In general the farmers were interested in preserving breadfruit but felt the process too cumbersome and unreliable. These conversations with the farmers resulted in a two step drying strategy which first emphasized fast and consistent shredding and then looked at both sun and passive solar drying. A robust manual shredder was designed ${ }^{31,32}$ and is currently undergoing an extended field test in Haiti. This paper examines the optimal ratio of surface area to volume as a parameter related to sun drying and has been shared with the Methodist, Catholic and Baptist ministries in Haiti.

\section{Materials AND Methods}

The following technical specifications were laid out as the basic guidelines to meet the breadfruit drying requirements:

- Dry nine square meters of breadfruit during clear sunny weather with average ambient temperatures of 29 degrees $\mathrm{C}, 60-70 \%$ relative humidity, and direct beam solar radiation of about $800 \mathrm{~W} / \mathrm{m}^{2}$.

- Reduce the moisture of a load of breadfruit to storage safe conditions from $70 \%$ moisture content to $10-13 \%$ moisture content in less than one day with minimal user effort and process cost. 
Three laboratory experiments were performed to determine the optimal shred size and base background for breadfruit sun drying. The laboratory results were then verified under average Caribbean conditions.

\section{Surface Area to Volume Ratio: Shred size Experiment}

This experiment investigates the shredding, handling, and drying characteristics of several different shapes and sizes of potato pieces. Potatoes were used because they are readily available in Minnesota. There are two basic shapes called "shreds" and "slices." Shreds are those pieces that are produced using a grating element with aligned holes, and have a shape approximated by a rectangular prism; slices are simply thin, cross-sectional cuttings of the potato and are shaped as closed cylinders. For the remainder of the paper all pieces will be referred to as shreds, unless commentary is being made specifically about the "slice" shape.

The equipment used in the experiment is listed in Table I. A modified electric food dehydrator was used to dry all shreds to a fully dry state. Fiberglass screen inserts were cut to fit the dehydrator's four drying trays to ensure that they would support even the smallest of shreds. The four trays were numbered 1-4 and stacked in ascending order from the bottom. The trays were always kept in this order during drying so that any effects on drying characteristics based upon position within the dehydrator could be monitored. The test procedure consists of shredding potatoes with commercially available graters with hole sizes of $0.635,0.9525$ and $1.27 \mathrm{~cm}(1 / 4$, $3 / 8,1 / 2$ inch). Using a dial caliper several selected shreds were measured. The average length, width, and thickness of the shreds and the initial mass of the slices and the drying tray were recorded. The loaded trays were placed in a food dehydrator (set to $54^{\circ} \mathrm{C}$ ), and the mass of the loaded trays was recorded every 10-15 minutes. The test was deemed complete after consecutive readings spanning at least 40 minutes yielded the same mass.

TABLE I.

EQUIPMENT USED FOR DETERMINATION OF SHRED SIZE

\begin{tabular}{|c|c|c|c|}
\hline Item Description & Manufacturer & Model \# & Serial \# \\
\hline Electric food dehydrator & American Harvest & FD50/30 & 39NZB145309 \\
\hline Electronic digital balance & Denver instruments & XP-3000 & $\mathrm{X} 010456$ \\
\hline Dial caliper & Rutland & G3104342 & N/A \\
\hline Adjustable cheese slicer & Target & $\mathrm{N} / \mathrm{A}$ & N/A \\
\hline Grater with $1 / 4$ in holes $(0.635 \mathrm{~cm})$ & Target & N/A & N/A \\
\hline Grater with $3 / 8$ in holes $(0.9525 \mathrm{~cm})$ & Target & $\mathrm{N} / \mathrm{A}$ & $\mathrm{N} / \mathrm{A}$ \\
\hline Grater with $1 / 2$ in holes $(1.27 \mathrm{~cm})$ & Target & N/A & N/A \\
\hline Metal mixing bowl & Target & N/A & N/A \\
\hline Fiberglass screen & Ace Hardware & N/A & N/A \\
\hline Russet potatoes & N/A & N/A & N/A \\
\hline Breadfruit & N/A & N/A & N/A \\
\hline Squash & N/A & N/A & N/A \\
\hline Butternut squash & N/A & N/A & N/A \\
\hline Eggplant & N/A & N/A & N/A \\
\hline
\end{tabular}

In addition to these objectively measured quantities, a number of other subjective observations were made during testing. The use of only one operator for all tests allowed for the subjective measures to be used reliably. A tradeoff chart was used to compile all numerical and subjective results as they related to the various types of shreds, and to determine the best shred type for the drying process. In this tradeoff chart, values of 1-4 were assigned to each shred type 
within each category, where 1 indicates the least desirable performance and 4 denotes the most desirable performance for that category. A brief description of the meaning of each category and criteria for how scores were assigned follows below:

- Drying Time: A numerical measure of the time taken for a shred type to dry to $15 \%$ moisture content. To accommodate the quickest overall system, a low drying time is best.

- Grating Force: A subjective measure comparing the perceived amount of force required to move the produce over the grater associated with each shred type; to accommodate ease of use in a manual process, low grating force is best.

- Grating Time: A subjective measure comparing the perceived amount of time necessary for a given grater to shred an entire potato. To accommodate the quickest overall system, a low grating time is best.

- Degree of Clogging: A subjective measure comparing the tendency of the graters producing the various shreds to become clogged. For ease of use and system quickness, low clogging is desirable.

- Ease of Handling/Spreading: A subjective measure comparing the ease with which various shred types could be handled and adequately spread out on the drying surface. In the interest of ease of use and system quickness, shreds that were easy to handle and adequately spread out were best.

- Space Utilization: A subjective measure comparing the ability to spread a given shred type out on the drying surface, while still making efficient use of the entire surface. To facilitate system quickness and capacity requirements, efficient space utilization is best.

\section{Breadfruit Correlation Testing}

A second experiment compared the drying characteristics of breadfruit with potatoes, squash, butternut squash and eggplant. Breadfruit shreds "smaller" for a given grating hole than potato. When potato is shredded, a measurable amount of water is removed by the mechanical action. Breadfruit does not exhibit any mechanical dewatering. Thus, this experiment was done to find an acceptable laboratory alternative to breadfruit. The experiment varied the tested produce while keeping a grater hole of $1.27 \mathrm{~cm}(1 / 2$ in) constant for all tests. The produce was compared to find a product with shredding and drying characteristics most similar to breadfruit. Again, all produce shreds were dried in an electric food dehydrator to a fully dried condition.

\section{Base Material Test Using Design of Experiments (DOE) Techniques}

This experiment investigated the key design factors in the design of solar collectors to determine if a black base or a base with higher thermal storage further accelerate drying. A four factor, half-fractional factorial Design of Experiment (DOE) ${ }^{33}$ was run in order to systematically vary the following factors:

Factors to Test:

a) Base material

b) Paint type

c) Thermal storage material

d) Surface area

Factor Low/High Levels to Test:

a) Plywood / Sheet steel

b) Glossy Black / Matte Black 
c) $0 \mathrm{~g} / 750 \mathrm{~g}$ of charcoal

d) $0.0645 \mathrm{~m}^{2}\left(100 \mathrm{in}^{2}\right) / 0.0967 \mathrm{~m}^{2}\left(150 \mathrm{in}^{2}\right)$ (achieved using either flat or corrugated base)

Response to Measure Progress:

a) Peak air temperature at 420 seconds approximately $1.9 \mathrm{~cm}(3 / 4 \mathrm{inch})$ from the base of the collector and percent of peak temperature after 700 seconds.

The objective of the experiment was to create a theoretical model of the system to determine the combination of conditions that could make sun drying most effective. The equipment used for the experiment is listed in Table II.

TABLE II

EQUIPMENT USED FOR BASE MATERIAL DOE

\begin{tabular}{|l|l|l|}
\hline Item Description & Manufacturer & Model \& Serial \# \\
\hline Agilent Benchlink data logger & Agilent & $34970 \mathrm{~A} / \mathrm{RS} 232$ \\
\hline Type K thermocouple & Omega & N/A \\
\hline Halogen light bulb with reflector & Home Depot & N/A \\
\hline $1 \mathrm{ft}^{3}$ wood box $(0.3 \mathrm{~m}$ x $0.3 \mathrm{~m} \times \mathrm{x} 0.3 \mathrm{~m})$ & N/A & N/A \\
\hline Sheet metal tower $3 \mathrm{ft}$ tall $(0.91 \mathrm{~m})$ & Home Depot & N/A \\
\hline Corrugated glossy black wood base & N/A & N/A \\
\hline Corrugated glossy black aluminum base & N/A & N/A \\
\hline Corrugated matte black wood base & N/A & N/A \\
\hline Corrugated matte black aluminum base & N/A & N/A \\
\hline Flat glossy black wood base & N/A & N/A \\
\hline Flat glossy black aluminum base & N/A & N/A \\
\hline Flat matte black wood base & N/A & N/A \\
\hline Flat matte black aluminum base & N/A & N/A \\
\hline Charcoal briquets $750 \mathrm{~g}$ & Kingsford & N/A \\
\hline
\end{tabular}

A 0.9 meter ( 3 foot) sheet metal tower was placed over a $0.3 \mathrm{~m} \times 0.3 \mathrm{~m} \times 0.3 \mathrm{~m}\left(1 \mathrm{ft}^{3}\right)$ wooden box. The bases were approximately $25 \mathrm{~cm}$ x $25 \mathrm{~cm}\left(100 \mathrm{in}^{2}\right)$ and were placed in the box. The corrugated base was built to provide more surface area in the same rectangular footprint. The average height of the corrugation was $5 \mathrm{~cm}$ ( 2 in) creating a total surface area of $0.967 \mathrm{~m}^{2}(150$ $\mathrm{in}^{2}$ ). A halogen light bulb with reflector was positioned at the top of the tower and was directed such that the light shined directly down the tower. The light bulb was chosen due to its high filament temperature of $3600 \mathrm{~K}$, which produces light in wavelengths closely simulating solar radiation. A type $\mathrm{K}$ thermocouple was secured approximately $1.9 \mathrm{~cm}$ from the base and was connected to an Agilent Benchlink data logger to continuously monitor air temperature. The tower, box and light bulb were cooled to room temperature before each trial. The data logger was turned on for exactly 60 seconds at which time the lamp was plugged in and the apparatus was run for exactly 6 minutes without interruption. After 6 minutes of run time, the light bulb was unplugged and the data logger was allowed to run for an additional 5 minutes.

\section{Breadfruit Sun Drying}

To substantiate the laboratory experiments breadfruit was processed and sun dried in the Caribbean. Breadfruit was shredded with a $1.27 \mathrm{~cm}(1 / 2$ inch $)$ hole shredding disk, loaded on fiberglass screened trays and placed in the sun on the island of St. Vincent in the West Indies between March 19 ${ }^{\text {th }}, 2004$ and March 24 ${ }^{\text {th }}$, 2004. Ambient temperatures and relative humidity, 
air velocities, incoming solar heat flux, and the mass of the breadfruit, was recorded by 2 people every 30 minutes. The equipment used is listed in Table III. Five different bases were placed under the screens. The bases and their intended improvement in parentheses are as follows:

- Plain tray placed in the grass (control)

- Plain tray placed in the grass, raised $15 \mathrm{~cm}$ (6 inches) off the ground (increase airflow)

- Tray placed in the grass with black collector plate placed below (increase temperature)

- Tray placed in the grass, raised $15 \mathrm{~cm}$ (6 inches) off the ground, with black perforated collector below (increase temp. and airflow)

- Tray placed in grass with reflector directing additional solar radiation on the breadfruit (increase incident solar energy and temp.)

TABLE III

EQUIPMENT USED FOR BREADFRUIT SUN DRYING TRIALS

\begin{tabular}{|l|l|l|}
\hline Item Description & Manufacturer & Model and Serial \# \\
\hline Air velocity meter & Omega & $\mathrm{HHF} 615 \mathrm{M} / 70342$ \\
\hline Thermometer/hygrometer & Omega & RH20F/ 200-03-11395 \\
\hline Thin film flux sensor & Omega & $\mathrm{HFS}-4 /$ O4018707 \\
\hline Polder balance & Polder & N/A \\
\hline Digital thermometer & Omega & $\mathrm{HH} 82$ 76JY0195 \\
\hline Type K thermocouples & Omega & N/A \\
\hline Breadfruit trays & University of St. Thomas (UST) & N/A \\
\hline Shredded breadfruit & N/A & N/A \\
\hline
\end{tabular}

\section{RESUlTS AND Discussion}

\section{Surface Area to Volume Ratio: Shred size Experiment}

The mass over time was measured for three shred sizes and two slice sizes. A representative drying curve is shown in Figure 1. The key feature to note about drying curves is that there is an initial region in which water content decreases linearly, followed by a region characterized by a dramatic decrease in the drying rate as the product reaches a low mass water content. For comparison of shred drying performance, a final water content of $40 \%$ was chosen because it consistently falls upon the linear portion of the drying curve for potatoes. 


\section{Drying Curve: Potato $0.635 \mathrm{~cm}(1 / 4 ")$ Grating Holes}

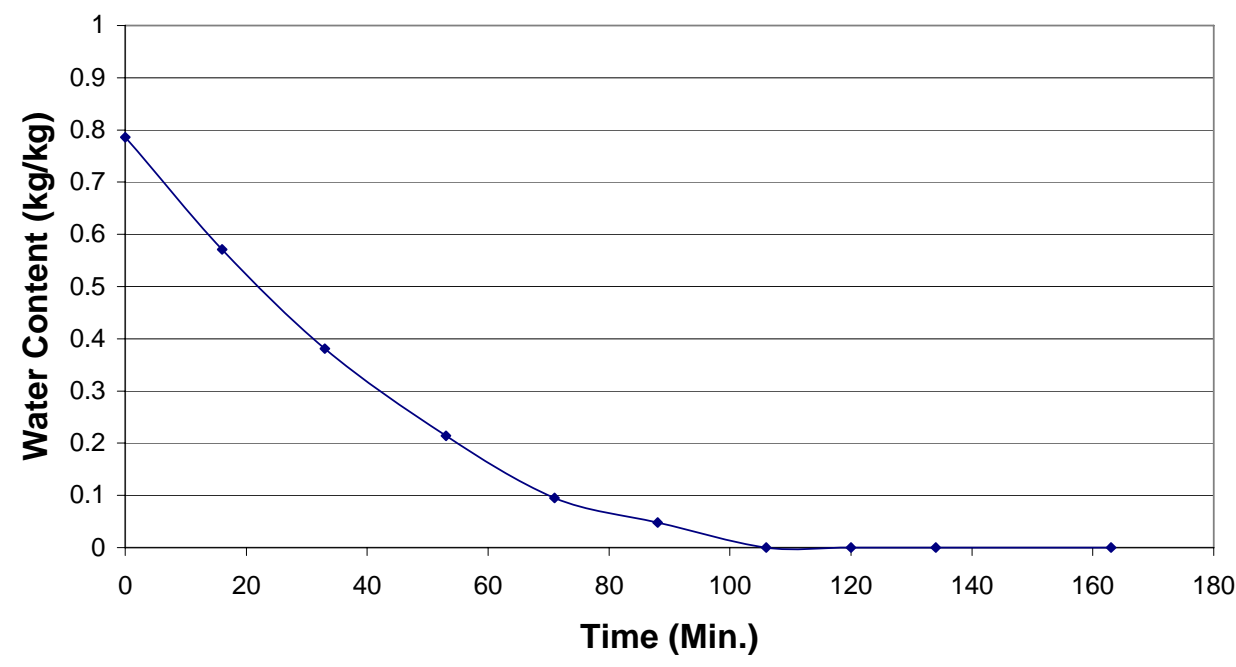

FIGURE 1

A REPRESENTATIVE DRYING CURVE EXHIBITED BY POTATOES SHREDDED WITH A $0.635 \mathrm{CM}(1 / 4 \mathrm{INCH})$ GRATING ELEMENT.

The average dimensions of each shred type (length, width, and thickness) of 5 random samples were used to approximate the shreds as rectangular prisms. In the case of a slice an average diameter was used to approximate a cylindrical prism. The ratio of average surface area to volume ratios was calculated. This ratio is the defining feature of a given shred type. A summary of all measured quantities for each shred type appears in Table IV, and the complete tradeoff chart appears in Table V.

TABLE IV

KEY MEASURED QUANTITIES FOR SHRED SIZE EXPERIMENT

\begin{tabular}{|c|c|c|c|c|}
\hline $\begin{array}{l}\text { Shred/Slice } \\
\text { Type }\end{array}$ & $\begin{array}{l}\text { Grating Hole Size } \\
\text { or slicer thickness }\end{array}$ & $\begin{array}{l}\text { Average Dimensions } \\
\text { of } 5 \text { random piece } \\
\text { (cm) }\end{array}$ & $\begin{array}{l}\text { Surface Area/Volume } \\
\text { Ratio } \\
\mathbf{c m}^{-1} \text { (1/in) } \\
\text { Ratio }=\frac{\text { Surface Area }}{\text { Volume }}\end{array}$ & $\begin{array}{l}\text { Time to Dry to } 40 \% \\
\text { Mass Water Content } \\
\text { (min) }\end{array}$ \\
\hline small shreds & $\begin{array}{l}0.635 \mathrm{~cm} \times 0.165 \\
\mathrm{~cm}(1 / 4 ” \mathrm{x} \\
0.065 ")\end{array}$ & $\begin{array}{l}\mathrm{w}=0.27 \\
\mathrm{l}=3.15 \\
\mathrm{t}=0.13\end{array}$ & $24.0(61.0)$ & 31.3 \\
\hline $\begin{array}{l}\text { medium } \\
\text { shreds }\end{array}$ & $\begin{array}{l}0.9525 \mathrm{~cm} \times 0.165 \\
\mathrm{~cm} \mathrm{(3/8”x} \\
0.065 ")\end{array}$ & $\begin{array}{l}\mathrm{w}=0.63 \\
\mathrm{l}=5.27 \\
\mathrm{t}=0.23\end{array}$ & $12.2(31.0)$ & 30.4 \\
\hline large shreds & $\begin{array}{l}1.27 \mathrm{~cm} \mathrm{x} 0.279 \mathrm{~cm} \\
(1 / 2 " x 0.110 ")\end{array}$ & $\begin{array}{l}w=1.27 \\
1=4.88 \\
t=0.37\end{array}$ & $7.4(18.9)$ & 35.8 \\
\hline slice & $\begin{array}{l}0.254 \mathrm{~cm} \\
\left(0.1^{\prime \prime)}\right.\end{array}$ & $\begin{array}{l}\mathrm{d}=3.71 \\
\mathrm{t}=0.34\end{array}$ & $6.9(17.6)$ & 44.2 \\
\hline
\end{tabular}


TABLE V

TRADEOFF CHART FOR SHRED SIZE COMPARISON

\begin{tabular}{|l|l|l|l|l|l|l|l|}
\hline $\begin{array}{l}\text { Shred } \\
\text { Type }\end{array}$ & $\begin{array}{l}\text { Drying } \\
\text { Time }\end{array}$ & $\begin{array}{l}\text { Grating } \\
\text { Force }\end{array}$ & $\begin{array}{l}\text { Grating } \\
\text { Time }\end{array}$ & $\begin{array}{l}\text { Degree of } \\
\text { Clogging }\end{array}$ & $\begin{array}{l}\text { Ease of } \\
\text { Handling/ } \\
\text { Spreading }\end{array}$ & $\begin{array}{l}\text { Space } \\
\text { Utilization }\end{array}$ & Totals \\
\hline $\begin{array}{l}\text { Small } \\
\text { shreds }\end{array}$ & 3 & 4 & 2 & 1 & 1 & 2 & 13 \\
\hline $\begin{array}{l}\text { Medium } \\
\text { shreds }\end{array}$ & 4 & 3 & 3 & 2 & 4 & 4 & 20 \\
\hline $\begin{array}{l}\text { Large } \\
\text { shreds }\end{array}$ & 2 & 2 & 4 & 3 & 3 & 3 & 17 \\
\hline slice & 1 & 1 & 1 & 4 & 2 & 1 & 10 \\
\hline
\end{tabular}

Based on the trade-off criteria, it was determined that the medium shreds, those shreds with a dimensional ratio of $12\left(\mathrm{~cm}^{-1}\right)$, are the best overall shape and size for all aspects of the shredding and drying process. Indeed, shreds of this configuration facilitate quick and efficient drying, and are easy to shred and handle. Breadfruit shreds at about this ratio when $1.27 \mathrm{~cm}(1 / 2 \mathrm{inch})$ grating holes were used.

\section{Breadfruit Correlation Testing}

The quantities used to compare the various types of produce included initial percent water content by mass, shred surface area to volume ratio for a given shredder hole size, and time to dry to $40 \%$ mass water content from initial condition. The surface area to volume ratio, as before, was calculated using average length, width, and thickness dimensions of the shreds, and approximating the shred shape as a rectangular prism.

The results from Table VI suggest that butternut squash is clearly the closest test surrogate for breadfruit. Butternut squash closely matches the characteristics of breadfruit on all measures, varying by just a few percent on any of them.

TABLE VI

SUMMARY BEHAVIOR FOR A FIXED GRATING HOLE SIZE OF $1.27 \mathrm{CM}(1 / 2 \mathrm{IN})$

\begin{tabular}{|l|l|l|l|}
\hline Produce Type & $\begin{array}{l}\text { Initial Mass \% } \\
\text { Water (\%) }\end{array}$ & $\begin{array}{l}\text { Surface Area/Volume Ratio } \\
\mathbf{c m}^{-1} \mathbf{( 1 / i n )} \\
\text { Ratio }=\frac{\text { Surface Area }}{\text { Volume }}\end{array}$ & Drying Time (min) \\
\hline Eggplant & 91.8 & $5.5(13.9)$ & 46.6 \\
\hline Potato & 78.0 & $7.4(18.9)$ & 35.8 \\
\hline Squash & 84.8 & $13.0(33.1)$ & 34.4 \\
\hline Butternut Squash & 76.3 & $12.3(31.4)$ & 29.0 \\
\hline Breadfruit & 72.0 & $11.6(29.6)$ & 30.1 \\
\hline
\end{tabular}

\section{Base Material Test Using Design of Experiments (DOE) Techniques}

The experiment set-up and results are presented in Table VII. The DOE did not yield a theoretical model for test system performance. Using commercial analysis software ${ }^{34}$ based on Analysis of Variance (ANOVA) methods, it was found that none of the factors tested statistically 
affect the two responses more than any other factor. Thus, no coded equation or model was able to be determined for the system to predict performance. Essentially, none of the tested factors significantly affect peak air temperature within this system or the retention of thermal energy within the system. Thus any combination of the tested factors will yield a satisfactory and statistically equivalent temperature. Thus, the base material, paint type, and surface area (corrugation) employed for the base should be chosen based upon practical considerations such as availability, sustainability and cost.

TABLE VII

DOE SET-UP AND MEASURED RESPONSE FOR DIFFERENT BASE MATERIALS

\begin{tabular}{|l|l|l|l|l|l|l|l|}
\hline Std & Run & $\begin{array}{l}\text { Factor 1 } \\
\text { Material }\end{array}$ & $\begin{array}{l}\text { Factor 2 } \\
\text { Paint Type }\end{array}$ & $\begin{array}{l}\text { Factor 3 } \\
\text { Thermal } \\
\text { Storage }\end{array}$ & $\begin{array}{l}\text { Factor 4 } \\
\text { Surface } \\
\text { Area }\end{array}$ & $\begin{array}{l}\text { Response 1 } \\
\text { Maximum Air } \\
\text { Temperature } \\
\text { deg C }\end{array}$ & $\begin{array}{l}\text { Response 2 } \\
\text { Fraction of } \\
\text { Maximum } \\
\text { Temperature at } \\
\text { 700 s }\end{array}$ \\
\hline 6 & 1 & Aluminum & Flat Black & yes & 1.00 & 52.22 & 0.58 \\
\hline 3 & 2 & Wood & $\begin{array}{l}\text { Glossy } \\
\text { Black }\end{array}$ & no & 1.00 & 65.38 & 0.56 \\
\hline 13 & 3 & Wood & Flat Black & yes & 1.41 & 56.30 & 0.63 \\
\hline 4 & 4 & Aluminum & $\begin{array}{l}\text { Glossy } \\
\text { Black }\end{array}$ & no & 1.00 & 50.78 & 0.72 \\
\hline 12 & 5 & Aluminum & $\begin{array}{l}\text { Glossy } \\
\text { Black }\end{array}$ & no & 1.41 & 52.11 & 0.68 \\
\hline 15 & 6 & Wood & $\begin{array}{l}\text { Glossy } \\
\text { Black }\end{array}$ & yes & 1.41 & 80.26 & 0.44 \\
\hline 10 & 7 & Aluminum & Flat Black & no & 1.41 & 48.32 & 0.75 \\
\hline 14 & 8 & Aluminum & Flat Black & yes & 1.41 & 83.21 & 0.41 \\
\hline 1 & 9 & Wood & Flat Black & no & 1.00 & 76.51 & 0.45 \\
\hline 7 & 10 & Wood & $\begin{array}{l}\text { Glossy } \\
\text { Black }\end{array}$ & yes & 1.00 & 58.42 & 0.60 \\
\hline 16 & 11 & Aluminum & $\begin{array}{l}\text { Glossy } \\
\text { Black }\end{array}$ & yes & 1.41 & 59.75 & 0.58 \\
\hline 2 & 12 & Aluminum & Flat Black & no & 1.00 & 39.93 & 0.69 \\
\hline 11 & 13 & Wood & $\begin{array}{l}\text { Glossy } \\
\text { Black }\end{array}$ & no & 1.41 & 68.56 & 0.59 \\
\hline 5 & 14 & Wood & Flat Black & yes & 1.00 & 62.48 & 0.57 \\
\hline 8 & 15 & Aluminum & $\begin{array}{l}\text { Glossy } \\
\text { Black }\end{array}$ & yes & 1.00 & 59.70 & 0.58 \\
\hline 9 & 16 & Wood & Flat Black & no & 1.41 & 46.58 & 0.77 \\
\hline
\end{tabular}

\section{Breadfruit Sun Drying}

The total solar radiation heat flux averaged $825 \mathrm{~W} / \mathrm{m}^{2}$, ambient temperatures ranged from 27$30^{\circ} \mathrm{C}$ and ambient relative humidity was $60-65 \%$. Prevailing winds averaged $1.5-2.0 \mathrm{~m} / \mathrm{s}$ throughout testing. All test configurations produced completely dried breadfruit shreds within +5 minutes of each other. This confirmed the base material experiment done in the laboratory. The base background has little effect on the breadfruit shred drying. The test was repeated with consistent results over three different days. The shreds repeatedly took about three hours to dry when placed in the direct sun. The optimal surface area to volume ratio of $12\left(\mathrm{~cm}^{-1}\right)$ dried the breadfruit shreds uniformly. Figure 2 shows the breadfruit sun drying. 


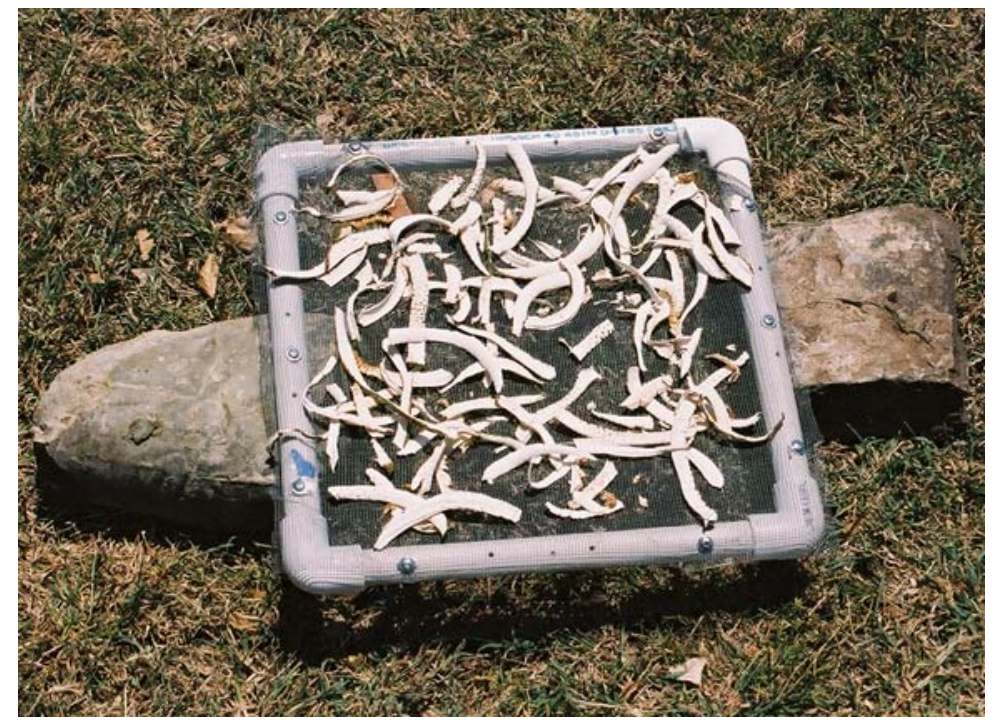

FIGURE 2

TESTING BREADFRUIT SHREDS IN ST. VINCENT.

\section{CONCLUSIONS}

To keep the total dehydration equipment cost to an affordable $\$ 10$ per family with about 10 families in one cooperative the authors recommended that small farmers invest in a manual shredder $^{31}$ that produces a surface area to volume ratio of $12\left(\mathrm{~cm}^{-1}\right)$ and dry the subsequent breadfruit shreds in the direct sun on any surface available or convenient surface. It is acknowledged that the open sun drying design affords no protection of the breadfruit product from rain, pests or dust. However the additional costs of an enclosed dryer or retractable protective cover would not be warranted at this time. It is more important to introduce the idea of food dehydration and to establish a mind frame of preserving surplus food. It is vital that the early adopters have success with the process strategy. Manual shredders and dehydration training will be implemented into six women's cooperatives in Haiti in a program of food processing directed toward village level entrepreneurs. Results have also been shared with Methodist, Catholic and Baptist ministries in Haiti. It is hoped that these results could benefit other communities in Oceania or the Caribbean to process breadfruit, an under utilized food and add to greater sustainability in food processing at a local level.

\section{ACKNOWLEDGMENT}

We would like to acknowledge funding from the Ireland Fund supported by the Lily Endowment through the Beyond Career to Calling project at UST and Mr. Larry Mathews. We would also like to thank J. Emiliusen, T. Mauritzen, Dr. Charlie Keffer, Erica McIntosh, Mary Schmitz and Dr. Ashley Shams for their help on-site in St. Vincent and Mr. Don Moran and all the volunteers at Compatible Technology International for their dedication and support in Minnesota. 


\section{REFERENCES}

1 "Prevention of post-harvest food losses: fruits, vegetables and root crops," section 11.3 Processing and preserving methods. FAO Training Series: no. 17/2, (1989); available from the Food and Nutrition Organization of the United Nations www.fao.org/docrep/T0073E/T0073E00.htm .

${ }^{2}$ D. Ragone, "Breadfruit. Artocarpus altilis (Parkinson) Fosberg," Promoting the conservation and use of underutilized and neglected crops 10. Institute of Plant Genetics and Crop Plant Research (1997); available from the Breadfruit Institute http://breadfruit.ntbg.org/resources/publications.php .

${ }^{3}$ L. Harrynanan, and C. Sankat, "The Thin-Layer Drying Characteristics of the Seeded Breadfruit or Breadnut," 2005 ASAE Annual Meeting, Tampa Florida, 17-20 July, (2005): Paper Number: 056157.

${ }_{5}^{4}$ I. Durandis. Interview by author. Pétionville, Haiti. July 2003.

${ }^{5}$ E. K. Akpinar and Y. Bicer, "Modeling of the drying of eggplants in thin layers," International Journal of Food Sciences and Technology 40 (2005): 273-281.

${ }^{6}$ O. Yaldýz and C. Ertekýn, “Thin layer solar drying of some vegetables,” Drying Technology 19, nos.3/4 (2001): 583-597.

${ }^{7}$ A. Midilli, H. Kucuk, and Z. Yapar, “A new model for single-layer drying,” Drying Technology 20, no. 7 (2002): 1503-1513.

${ }^{8}$ M.A. Basunia and T. Abe, "Thin-layer solar drying characteristics of rough rice under natural convection," Journal of Food Engineering 47 (2001): 295-301.

${ }^{9}$ İ. T. Toğrul and D. Pehlivan, "Modelling of thin layer drying kinetics of some fruits under open-air sun drying process," Journal of Food Engineering 65 (2004): 413-425.

${ }^{10}$ T. Koyuncu, I. Tosun, and N. S. Ustun, "Drying Kinetics and Color Retention of Dehydrated Rosehips," Drying Technology 21, no. 7 (2003): 1369-1381.

${ }^{11}$ B. Khiari, D. Mihoubi, S. Ben Mabrouk, and M. Sassi, "Experimental and numerical investigations on water behaviour in a solar tunnel drier," Desalination 168 (2004): 117-124.

${ }^{12}$ C. Ratti and A.S. Mujumdar, "Solar drying of foods: Modeling and Numerical Simulation," Solar Energy 60, nos. 3/4 (1997): 151-157.

${ }^{13}$ D. Ivanova and K. Andonov, “Analytical and experimental study of combined fruit and vegetable dryer," Energy Conversion and Management 42 (2001): 975-983.

${ }^{14}$ R. Ranjan, J. Irudayaraj, J.N. Reddy, and A.S. Mujumdar, "Finite-Element Simulation and Validation of Stepwise Drying of Bananas," Numerical Heat Transfer, Part A. 45 (2004): 997-1012.

${ }^{15}$ A. Esper and W. Mühlbauer, "Solar Drying- An Effective Means of Food Preservation," Renewable Energy 15 (1998): 95-100.

${ }^{16}$ S. Soponronnarit, "Solar drying in Thailand," Energy for Sustainable Development vol. II, no. 2 (1995): 19-25.

${ }^{17}$ V.K. Sharma, A. Colangelo, and G. Spagna, "Experimental investigation of different solar dryers suitable for fruit and vegetable drying," Renewable Energy 6, no. 4 (1995): 413-424.

${ }^{18}$ D. Scanlin, M. Renner, D. Domermuth, and H. Moody, "Improving Solar Food Dryers," Home Power 69 (1999): 24-34.

${ }^{19}$ A.A. El-Sebaii, S. Aboul-Enein, M.R.I. Ramadan and H.G. El-Gohary, "Experimental investigation of an indirect type natural convection solar dryer," Energy Conversion and Management 43 (2002): 2251-2266.

${ }^{20}$ H. Hallak, J. Hilal, F. Hilal, and R. Rahhal, "The Staircase Solar Dryer: Design and Characteristics," Renewable Energy 7, no. 2 (1996): 177-183.

${ }^{21}$ V.K. Sharma, A. Colangelo, and G. Spagna, "Experimental performance of an indirect type solar fruit and vegetable dryer," Energy Conversion Management 34, no. 4 (1993): 293-308.

${ }_{22}$ M. Tiris and I. Dincer, "Experimental testing of a new solar dryer," International Journal of Energy Research 18 (1994): 483-490.

${ }^{23}$ Home Garden Technology Leaflet 18, Processing, preservation and storage http://www.fao.org//docrep/003/x3996e/x3996e42.htm

${ }^{24}$ G. Ewing, Breadfruit Flour Analysis, 4 February 1996, personal communication with Compatible Technologies International. 
${ }^{25}$ R. Beyer, "Strategies for the Augmentation of Food Activities in Pohnpei," Report sponsored by the Centres for Disease Control and Prevention and the United Nations Children's Fund (2004).

${ }^{26}$ B. Bena and R.J. Fuller, "Natural Convection Solar Dryer with Biomass Back-up Heater," Solar Energy 72, no.1 (2002): 75-83.

${ }^{27}$ M.S. Rahman, Handbook of Food Preservation (Marcel Dekker, 1999), 201.

${ }^{28}$ B. Kerr, "A Review of Solar Food Drying," available from The Solar Cooking Archive http://solarcooking.org/dryingreview.htm .

${ }^{29}$ J.P. Rowe, A.R. Sloan, and F.M. Steele, "Long-term preservation of cassava, taro, and breadfruit by solar-drying in the Pacific Islands area," Institute of Food Tecnologists (IFT) Annual Meeting, July 12-16-Las Vegas, NV (2004) http://ift.confex.com/ift/2004/techprogram/paper_25967.htm .

${ }^{30}$ J.P. Rowe and F.M. Steele, "Solar Dryer Construction and Use Manual," Department of Nutrition, Dietetics, and Food Science, Brigham Young University (2004).

${ }^{31}$ M. Andersen, B. Fox, B. Rick, and A. Spah, "Design of a manually operated food shredder for the developing world," University of St. Thomas Senior Design final report available from http://courseweb.stthomas.edu/cmgeorge/projects/english/manual shredding/manualShredding.htm

32 J. Weiss, C. George, and J. Walker, "Redesigning an Appropriate Technology Shredder for Manufacture in a Developing Country," The International Journal for Service Learning in Engineering 1, no. 1 (2006): 11-26.

${ }^{33}$ J. Antony, Design of Experiments for Engineers and Scientists (Elsevier Butterworth-Heinemann, 2005) Chapter 7.

${ }^{34}$ Design-Expert Version 6.0.10, Stat-Ease, Inc. www.statease.com 